\title{
A Look Back at the Czechoslovak Family \\ Business Day, which Included a Conference \\ Entitled Family Business, Intergenerational \\ Milestones and Generators of Value \\ Ohlédnutí za Česko-slovenským dnem rodinného \\ podnikání, jehož součástí byla i konference \\ s názvem Rodinné podnikání - Mezigenerační \\ milníky a generátory jejich hodnoty
}

\section{NADĚŽDA PETRŮ}

\section{DOI}

http://dx.doi.org/10.37355/acta-2021/2-06

University of Finance and Administration has been researching the specifics of family business since 2014. The theory of family business should be able to distinguish family businesses from non-family businesses, it should respond to changes in the political, economic, social, technological, environmental environment, as well as to changes in the purchasing and consumption behaviour of customers, trends in the use of information and communication technologies in the theory and real practice of family businesses. The emergence of family businesses has brought together three systematically different worlds - the world of emotions with the world of rationality and the world of family and corporate asset management. Their supporting specificity is the interaction of family and business, the interaction between the rational and performance-oriented world of business and the emotional family ties and relationships. The research carried out shows that the basic principles of their success include wisdom and know-how passed on from generation to generation, pride, trust, tenacity, flexibility, a stable corporate culture, speed of decisionmaking, loyalty, honesty, ethics, responsibility towards the next generation, the ability to motivate people in their environment, support the development of the region etc. These characteristics gradually become an important generator of values, emotional or social, i.e. non-economic wealth of family business.

In 2021, approximately 31 years have passed since the first family businesses were founded in the Czechia and Slovakia - the first ever modern intergenerational exchange is taking place, which is associated with many unresolved issues - the transfer of management, ownership, conflict resolution, innovation, diversification, risk management etc. The conference, held on 21 September, aimed at exchanging information, experiences and presenting research results not only from academic institutions in the field of management and promotion of FP. It was one of the outcomes of the TA CR project TL02000434 entitled Family businesses: generators of value and determination of value in the process of succession. Thanks to the participation of about 78 interested persons from the Czechia, 
Slovakia, but also from Poland and Hungary, from the ranks of academics, consulting firms, Associations, representatives of the state sphere and real owners, the goal was fully fulfilled. During the conference session, a number of stimulating contributions were made, focusing e.g. on the social perception of FP, the impact of the COVID pandemic and the resilience of $\mathrm{FP}$, the mediating role of social capital, rational initiatives as a prerequisite for sustainability, the importance of diagnostic auditing, the potential of intellectual property protection etc. Different methods used by academics were discussed, e.g. the vitality assessment model, the F-PEC model, the CHROMA model etc., and participants also assessed the limits of research on this social group and expected future topics.

Then, at the end of the day, a joint Declaration on the development of family business towards governments was approved. An example of the themes is:

- promote investment and sustainability of family businesses as drivers of national economies,

- to encourage family business owners to reinvest their own resources, especially in the development of their businesses,

- develop the availability of lifelong learning and advice on family business,

- in connection with the legal anchoring of the definition of family businesses and their activities in the Czech Republic and Slovakia, to support related adjustments to existing legislation etc.

The participants unanimously declared that they will always assist the governments of the Czech Republic and the Slovak Republic in the implementation of their intentions, because they see the perspective and future of our countries in family business. 